\section{Eureka}

\section{Secretariat in search of base}

Project Eureka continues to make progress towards its goal of promoting European cooperation in high technolgy projects, but like most multinational cooperative ventures, some steps are disappointingly slow.

On the positive side, the Eureka High Representatives at their meeting in London late last month announced that new collaborative efforts are making "significant progress". Sixteen projects have achieved full-fledged Eureka status, with 25 more close on their heels.

But the last ministerial conference on Eureka held in Hannover set 31 January 1986 as the deadline for establishing the location and structure of the Eureka secretariat, and that deadline has passed with no decisions on location, although the group did agree on the basic structure and scope of the secretariat.

The site for the secretariat is significant for several reasons. While Brussels is favoured by a majority, some countries are concerned that Eureka should not become a satellite of the European Economic Community, especially since six of the

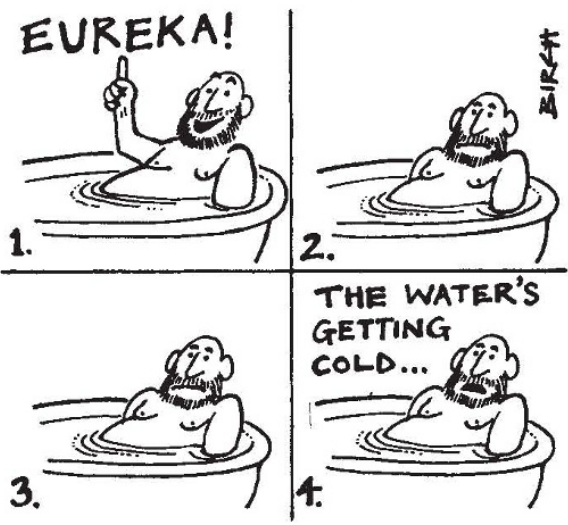

18 nations participating in Eureka do not belong to the Community. But a more sticky objection to Brussels has been raised by the French. France has been the moving force behind Eureka since its inception, and Strasbourg is the French choice for the headquarters.

Brian Oakley, current chairman of the Eureka High Representatives, calls the delay in selecting a site "very annoying", but he believes that the situation may be resolved next March. By then the French elections will have passed, and it will politically acceptable for France to drop its insistence on Strasbourg.

The powers of the new secretariat are also important, as the smaller members are concerned to maintain some political muscle against the big four (France, Britain, West Germany and Italy). The new secretariat will consist of 12 people, half of them professional staff. Its principal function will be information dissemination and

European neutrons coordination of activities. One key decision of the recent meeting of Eureka High Representatives was to set approval of plans for the secretariat at the administrative level, rather than by formal treaty.

A provisional mechanism for approving projects for inclusion in the Eureka scheme is also now in place. Once two companies agree on a cooperative venture, there will be a 45 -day period during which other countries may suggest their own companies as partners to the proposed project, although there is no guarantee that partnership status will in the end be granted.

\title{
British aiming to share costs
}

THE British hope to gain substantially from attempts now being made to internationalize European neutron and synchrotron radiation sources. Hopes turn on a meeting arranged by the British Science and Engineering Research Council (SERC) for next Tuesday (18 February) at which representatives of France and Italy will discuss proposals for a substantial extension of the Spallation Neutron Source, commissioned a year ago at the Rutherford Appleton Laboratory in Oxfordshire.

The proposed extension of the Spallation Neutron Source, which goes under the new name of ISIS, would cost $£ 60$ million over ten years, of which a half would be met by SERC and the remainder by the other participants. But overseas participation in the project is a trade-off against British collaboration in the European Synchrotron Radiation Facility (ESRF) to be built at Grenoble in France, and to which the SERC contribution will be more than 15 per cent of the total construction cost of $£ 150$ million, at $£ 24$ million.

According to officials of potential partners, SERC has indicated unofficially but firmly that British participation in ESRF will be forthcoming only if the cost of the proposed ISIS project is shared with European partners. Indeed, SERC is looking not merely for a 50 per cent contribution to the cost of the extension, but for an "entry fee" of roughly a half of the cost of building the neutron source as it stands, which might amount to a total of $£ 50$ million. If these hopes materialize, SERC will be laying out $£ 26$ million less than it receives by way of contributions to ISIS.

Apart from France and Italy, other possible participants in the ISIS project include Denmark, Sweden, the Netherlands and Spain, some of whom may be
Oakley sees opening up the market as a key role of Eureka. He is anxious to expand the international awareness of member companies, in part through management seminars bringing together corporate executives, financial experts and civil servants familiar with global issues.

Another important role for Eureka will be to encourage European standardization, perhaps along the lines of the British concept of "Eurotype", so as to smooth the path to market of Eureka projects.

According to Oakley, Eureka now enjoys full support from the British government. Whether it will ultimately succeed will depend not on the show of support it receives, but rather on the successful products it brings to the marketplace.

Joseph Palca represented as observers at next week's meeting. West Germany will also be in attendance, but only as an observer; the West German plan to build a superior spallation neutron source, the SNQ, was cancelled only last year.

More recently, the intriguing prospect has arisen of Australian collaboration in the British neutron projects, although the potential European partners have not yet been told of this possibility. Australia is aparently short of neutrons, and the proposed deal with SERC would give Australia free access to ISIS as a quid pro quo for a reduction of British spending on the Anglo-Australian Telescope, recently recommended by a SERC review committee.

Enthusiasm for an improvement of the existing spallation neutron source stems from the good performance of the machine during its first year of operation and from the circumstance that it is a rapidly pulsed machine, producing neutron beams with very high intensity. French physicists, less keen on more neutrons than the Australians, say that the existing machine offers experimentalists few advantages over the reactor-based neutron source now working at the Institut Laue-Langevin at Grenoble, but that the proposed extension could be more interesting.

The status of next week's meeting is not yet crystal clear. The goal, at that and at a nominally separate but parallel series of meetings on ESRF, is to reach intergovernmental agreements on the two projects by the middle of next year, if all goes well. But French sources say that the French interest in next week's meeting and the subsequent negotiations is to discover "what part of ISIS can be Europeanized", which would seem to offer the British less than they are looking for.

Robert Walgate 